\title{
Uji Sensitivitas Kunyit Kuning dan Kunyit Putih Terhadap Bakteri Pencemar Susu
}

\author{
Rezica Kanza Nobiola ${ }^{1}$, Tusy Triwahyuni ${ }^{2}$, Nia Triswanti ${ }^{3}$, Efrida Warganegara ${ }^{4}$ \\ ${ }^{1)}$ Fakultas Kedokteran Universitas Malahayati, rezaaanbl@gmail.com \\ ${ }^{2)}$ Departemen Parasitologi Fakultas Kedokteran Universitas Malahayati, tussythree@ gmail.com \\ ${ }^{3)}$ Departemen Biokimia Fakultas Kedokteran Universitas Malahayati, dr.niatriswanti82@gmail.com \\ 4) Departemen Mikrobiologi Fakultas Kedokteran Universitas Lampung, efrida_warganegara@yahoo.com
}

\begin{abstract}
ABSTRAK
Kunyit kuning (Curcuma longa) dan kunyit putih (Kaempferia rotunda) merupakan salah satu tanaman obat dan bumbu masakan yang banyak digunakan oleh sebagian besar masyarakat. Kunyit termasuk ke dalam famili Zingiberaceae merupakan tanaman obat yang diketahui memiliki kandungan antibakteri. Kandungan antibakteri yang terdapat dalam kunyit yaitu kurkuminoid dan minyak atsiri yang dipercaya mampu untuk membunuh dan menghambat bakteri. Tujuan dari penelitian ini adalah untuk mengetahui sensitivitas kunyit kuning dan kunyit putih terhadap bakteri pencemar susu penyebab foodborne disease menggunakan metode Kirby Bauer dengan teknik difusi disk. Desain penelitian menggunakan eksperimental. Ekstrak rimpang kunyit kuning dan kunyit putih diperoleh dengan cara diparut dan disaring setelah itu diuji terhadap bakteri pencemar susu penyebab foodborne disease menggunakan teknik difusi disk dengan masing - masing konsentrasi 12,5\%, 25\%, 50\% dan 100\%. Hasil peneltian menunjukkan ekstrak rimpang kunyit kuning dengan konsentrasi 12,5\%, 25\%, 50\% dan 100\% memdapatkan hasil diameter zona hambat $0 \mathrm{~mm}, 11,3 \mathrm{~mm}$, 15,3 $\mathrm{mm}$ dan $17 \mathrm{~mm}$. Sedangkan kunyit putih tidak menghasilkan zona hambat pada semua konsentrasi. Terdapat sensitivitas kunyit kuning terhadap bakteri pencemar susu penyebab foodborne disease menggunakan metode Kirby Bauer dengan teknik difusi disk dan tidak terdapat sensitivitas kunyit putih terhadap bakteri pencemar susu penyebab foodborne disease menggunakan metode Kirby Bauer dengan teknik difusi disk.
\end{abstract}

Kata kunci: Kunyit Kuning, Kunyit Putih, Foodborne Disease, Uji Sensitivitas.

\section{ABSTRACT}

Yellow turmeric (Curcuma longa) and white turmeric (Kaempferia rotunda) are one of the medicine plants and seasons that are used by most of the people. Turmeric belongs to the zingiberaceae family as a medicinal plant that is known to contain antibacterial substances. Antibacterial ingredients in turmeric, namely are curcuminoids and essential oils which are believed to be able to kill and inhibit bacteria. The purpose of this study is to know the sensitivity of yellow turmeric and white turmeric to milk contaminating disease using the Kirby Bauer method with a diffusion disk technique. The study design using experimental technique. Yellow turmeric rhizome extract and white turmeric were tested to the milk contaminating disease using diffusion disk technique with 12,5\%,25\%, 50\%, and 100\% concentration. Yellow turmeric rhizome extract with 12,5\%, 25\%, 50\%, and 100\% concentration showed results inhibition diameter zone: $0 \mathrm{~mm}, 11,3 \mathrm{~mm}, 15,3 \mathrm{~mm}$, and $17 \mathrm{~mm}$. On the other hand, white turmeric gets no result in the inhibition diameter zone for all concentration. This study showed there is a sensitivity of yellow turmeric to bacteria of milk-contamination that causes foodborne disease using the Kirby Bauer method with white turmeric disk diffusion technique. There is no sensitivity to bacteria of milk-contamination that causes foodborne disease using the Kirby Bauer method with disk diffusion technique.

Keyword : yellow turmeric, white turmeric, foodborne disease, sensitivity test.

* Korespondensi Author : Rezica Kanza Nobiola, Program Studi Kedokteran Fakultas Kedokteran Universitas Malahayati, rezaaanbl@gmail.com, telp.082127091338

\section{PENDAHULUAN}

Penyakit yang disebabkan atau ditularkan melalui makanan yang terkontaminasi oleh agen patogen penyebab penyakit biasa disebut dengan

istilah foodborne disease ${ }^{1}$.Makanan yang telah terkontaminasi oleh bakteri setelah dikonsumsi biasanya menimbulkan gejala - gejala seperti 
muntah - muntah, demam dan sakit perut. Gejala terjadi 4 - 12 jam yang memberi kesan langsung pada lapisan usus dan menyebabkan peradangan. Ada beberapa jenis bakteri yang dapat menyebabkan keracunan makanan, diantaranya Salmonella, Staphylococcus, dan Escherichiacoli. ${ }^{2}$

Penyakit bawaan makanan umumnya terjadi karena adanya kontaminasi oleh kontaminan yang secara tidak disengaja. ${ }^{3}$ Sumber makanan bergizi yang sering berpotensi menyebabkan keracunan salah satunya yaitu produk minuman susu. Keracunan yang ditimbulkan tersebut sebagai akibat adanya kontaminasi dan penanganan kurang tepat selama proses pengolahan sehingga susu mengalami kerusakan dan tidak layak untuk dikonsumsi. Hasil analisis Badan Pengawas Obat dan Makanan (BPOM) menyimpulkan bahwa penyebabnya adalah Eschericia coli dan Staphylococcus aureus. ${ }^{4}$

Selama ini penyakit infeksi diatasi dengan menggunakan antibiotika. Antibiotika merupakan golongan senyawa alami atau sintetis yang memiliki kemampuan untuk menekan atau menghentikan proses biokimiawi di dalam suatu organisme, khususnya proses infeksi bakteri. ${ }^{5}$ Penggunaan antibiotika yang tidak rasional bisa membuat mikroba patogen menjadi resisten ${ }^{6}$ dan munculnya mikroba resisten ini penyebab utama kegagalan pengobatan penyakit infeksi. ${ }^{7}$ Oleh sebab itu, diperlukan alternatif dalam mengatasi masalah ini dengan memanfaatkan bahan - bahan aktif antimikroba dari tanaman obat. ${ }^{6}$

Tanaman obat adalah tanaman yang mengandung bahan yang dapat digunakan sebagai pengobatan dan bahan aktifnya dapat digunakan sebagai bahan obat sintetik $^{8}$.Jenis tanaman obat yang banyak digunakan adalah famili zingiberaceae. ${ }^{9}$ Famili zingiberaceae merupakan jenis tumbuhan temu - temuan, yang memiliki rimpang dan berbau khas. ${ }^{10}$

Kunyit termasuk ke dalam famili Zingiberaceae merupakan tanaman obat dan bumbu masakan yang banyak digunakan oleh sebagian besar masyarakat di Indonesia dan India. Kunyit digunakan dalam berbagai bidang seperti kesehatan, kuliner, dan kosmetik. ${ }^{11}$ Kunyit mengandung bahan senyawa aktif yaitu kurkumin yang dapat berperan sebagai antitumor, antibakteri dan antioksidan. Kurkumin berwarna kuning alami dan termasuk kelompok senyawa polifenol yang dapat menyebabkan denaturasi protein dan merusak membran sel. ${ }^{12}$ Kurkumin sebagai senyawa fenolik mampu merusak dan menembus dinding sel bakteri kemudian mengendapkan protein sel mikroba. ${ }^{13}$

Tanaman obat lain yang termasuk ke dalam famili Zingiberaceae dan diyakini mempunyai banyak khasiat dan relatif aman adalah kunyit putih. Kunyit putih digunakan untuk pengobatan tradisional, kunyit putih merupakan tanaman semak tahunan yang tersebar di daerah tropis dan subtropis. ${ }^{14}$ Kunyit putih digunakan oleh masyarakat sebagai obat tradisional untuk mengobati demam, sebagai penenang, sakit perut (kolik/mules), memacu kontraksi otot perut, memacu sekresi empedu, hepatoprotektor, serta obat kanker. ${ }^{2}$

Ekstrak etanol rimpang kunyit putih dapat menghambat pertumbuhan bakteri Staphylococcus aureus dan Escherechia coli dengan beberapa variasi konsentrasi, hal ini dikarenakan kunyit putih mengandung lebih dari satu senyawa yang bersifat bakterisidal. ${ }^{15}$

Berdasarkan latar belakang di atas maka peneliti tertarik untuk meneliti lebih lanjut tentang Uji Sensitivitas Kunyit Kuning (Curcuma longa) Dan Kunyit Putih (Kaempefria rotunda) Terhadap Bakteri Pencemar Susu Penyebab Foodborne Disease.

\section{METODOLOGI}

Penelitian ini merupakan penelitian eksperimen, penelitian ini dilaksanakan pada bulan Februari 2020 setelah mendapatkan persetujuan laik etik dari komisi etik penelitian kesehatan (KEPK) Universitas Malahayati Bandar Lampung. Penelitian ini dilakukan di 
Laboratorium Infeksi Rumah Sakit Umum Kabupaten Tangerang.

Penelitian ini menggunakan susu kemasan UHT dengan tanggal yang sudah kedaluwarsa dan dilakukan uji koliform untuk mengetahui apakah terdapat cemaran bakteri atau tidak. Selanjutnya dilakukan uji sensitivitas menggunakan media Mueller Hinton Agar (MHA) kemudian masukkan disk antibiotik yang sudah terkandung ektrak rimpang kunying dan kunyit putih dengan masing - masing konsentrasi 12,5\%, 25\%, 50\% dan $100 \%$, inkubasi pada suhu $37^{\circ} \mathrm{C}$ selama 24 jam. Proses pembuatan perasan rimpang kunyit dilakukan dengan cara mencuci rimpang kunyit tanpa menghilangkan kulitnya hingga bersih lalu dikeringkan, kemudian rimpang kunyit dikupas lalu diparut. Hasil parutan tersebut diperas menggunakan kain saring setelah itu hasil saringan tersebut disimpan dalam botol steril kaca tertutup. ${ }^{16}$ Selanjutnya mengukur diameter zona hambat menggunakan penggaris dan dilakukan pengecetan gram.

\section{HASIL DAN PEMBAHASAN}

Penelitian mengenai uji sensitivitas kunyit kuning dan kunyit putih terhadap bakteri pencemar susu penyebab foodborne disease dengan menggunakan metode Kirby Bauer menggunakan teknik difusi disk diawali dengan melakukan uji koliform terhadap susu kemasan UHT dengan tanggal yang sudah kedaluwarsa. Uji koliform ini dilakukan untuk memastikan bahwa susu kemasan UHT dengan tanggal yang sudah kedaluwarsa ini dapat tercemar oleh bakteri koliform dan hasil uji koliform yang didapatkan sebagai berikut :

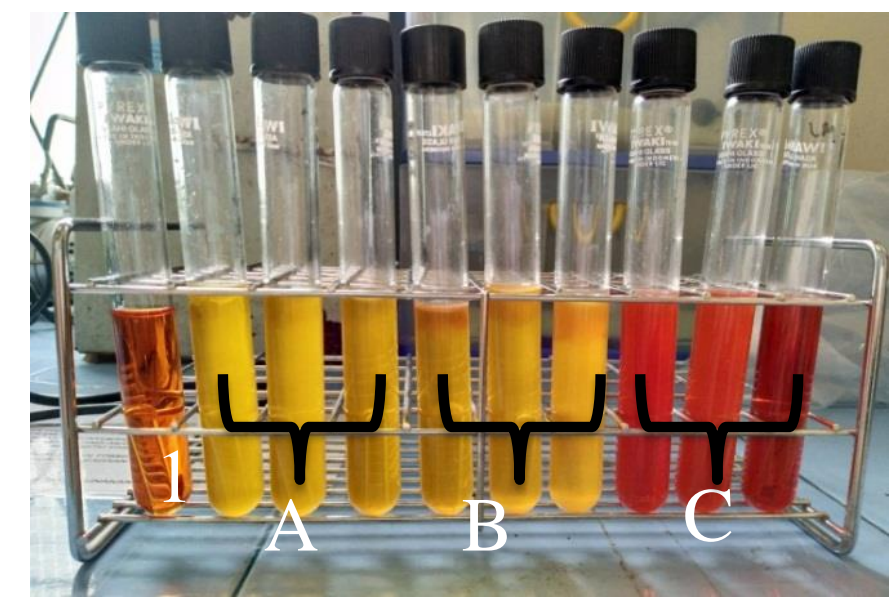

Gambar 1. Hasil Uji Koliform

Keterangan :1) Kontrol, (A) Pengenceran Pertama, (B) Pengenceran Kedua, (C) Pengenceran Ketiga

Indikator tabung positif pada uji koliform memiliki 3 poin yaitu tabung yang terdapat endapan, perubahan warna menjadi coklat muda dan terdapat gas pada tabung durham (minimal mengisi $2 / 3$ tabung). ${ }^{17}$ Pada penelitian uji koliform terhadap susu kemasan UHT dengan tanggal yang sudah kedaluwarsa didapatkan hasil : tabung seri A dan seri B positif mengandung coliform dikarenakan terjadi perubahan warna menjadi coklat muda sedangkan sedangkan seri $\mathrm{C}$ negatif atau tidak mengandung coliform.

Setelah dilakukan uji koliform selanjutnya dilakukan uji sensitivitas ekstrak kunyit kuning (Curcuma longa) dan kunyit putih (Kaempferia rotunda) terhadap bakteri pencemar susu penyebab foodborne disease menggunakan teknik difusi disk dengan seri konsentrasi 12,5\%, 25\%, $50 \%$ dan $100 \%$ disertai kontrol positif 
menggunakan tetrasiklin, dilakukan tiga kali pengulangan karena dalam uji mikrobiologi minimal pengulangan dilakukan sebanyak lima kali atau sebanyak 3 kali pengulangan. ${ }^{18}$

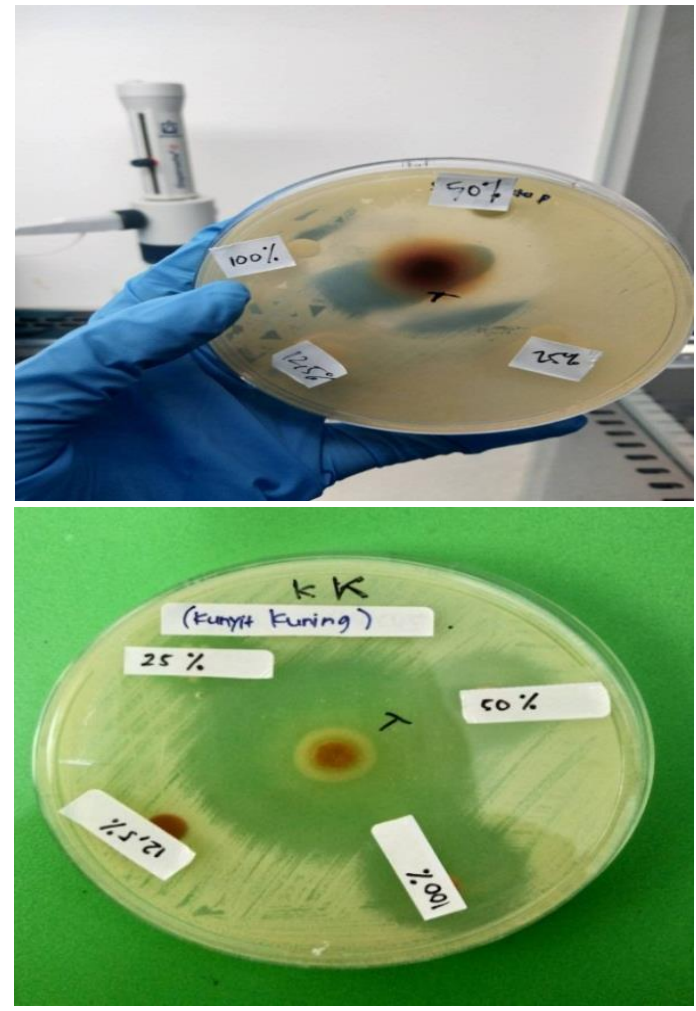

Gambar 2. Zona Hambat Kunyit Kuning dan Kunyit Putih

Setelah masa inkubasi selama 1 x 24 jam pada suhu $37^{\circ} \mathrm{C}$ hasil yang diperoleh dapat dilihat pada tabel 1 .

Tabel 1. Hasil Zona Hambat Ekstrak Kunyit Kuning

Zona Hambat Ekstrak Rimpang Kunyit (mm)

\begin{tabular}{|c|c|c|c|c|c|}
\hline \multirow[t]{2}{*}{ Pengulangan } & \multicolumn{4}{|c|}{ Kunyit Kuning } & Kontrol \\
\hline & $12,5 \%$ & $25 \%$ & $50 \%$ & $100 \%$ & $(+)$ \\
\hline 1 & - & - & - & - & 24 \\
\hline 2 & - & 14 & 18 & 20 & 40 \\
\hline 3 & - & 20 & 28 & 30 & 40 \\
\hline Rata - rata & - & 11,3 & 15,3 & 17 & 35 \\
\hline
\end{tabular}

Keterangan : Kontrol $+=$ Tetrasiklin
Berdasarkan tabel 1. hasil uji sensitivitas kunyit kuning terhadap bakteri pencemar susu penyebab foodborne disease menggunakan teknik difusi disk pada pengulangan kesatu konsentrasi $12,5 \%, 25 \%, 50 \%$ dan $100 \%$ tidak menunjukkan sensitivitas antibakteri atau tidak terbentuk zona hambat pada ketiga pengulangan. Pada pengulangan kedua terbentuk zona hambat pada konsentrasi $25 \%$ berukuran $14 \mathrm{~mm}$, zona hambat pada konsentrasi $50 \%$ berukuran $18 \mathrm{~mm}$ dan zona hambat pada konsentrasi $100 \%$ berukuran $20 \mathrm{~mm}$. Pada pengulangan ketiga terbentuk zona hambat pada kosentrasi $25 \%$ berukuran $20 \mathrm{~mm}$, zona hambat pada kosentrasi $50 \%$ berukuran $28 \%$ dan zona hambat pada konsentrasi $100 \%$ berukuran 30 $\mathrm{mm}$.

Tabel 2. Hasil Zona Hambat Ekstrak Kunyit Putih

\begin{tabular}{cccccc}
\hline \multicolumn{4}{c}{ Zona Hambat Ekstrak Rimpang Kunyit (mm) } \\
\hline Pengulangan & \multicolumn{4}{c}{ Kunyit Putih } & Kontrol \\
\hline & $12,5 \%$ & $25 \%$ & $50 \%$ & $100 \%$ & $(+)$ \\
1 & - & - & - & - & 24 \\
2 & - & - & - & - & 40 \\
3 & - & - & - & - & 40 \\
\hline Rata - rata & - & - & - & - & 35 \\
\hline
\end{tabular}

Keterangan : Kontrol $+=$ Tetrasiklin

Pada hasil uji sensitivitas kunyit putih pada konsentrasi $12,5 \%, 25 \%, 50 \%$ dan $100 \%$ dari pengulangan kesatu sampai dengan ketiga tidak terbentuk zona hambat.

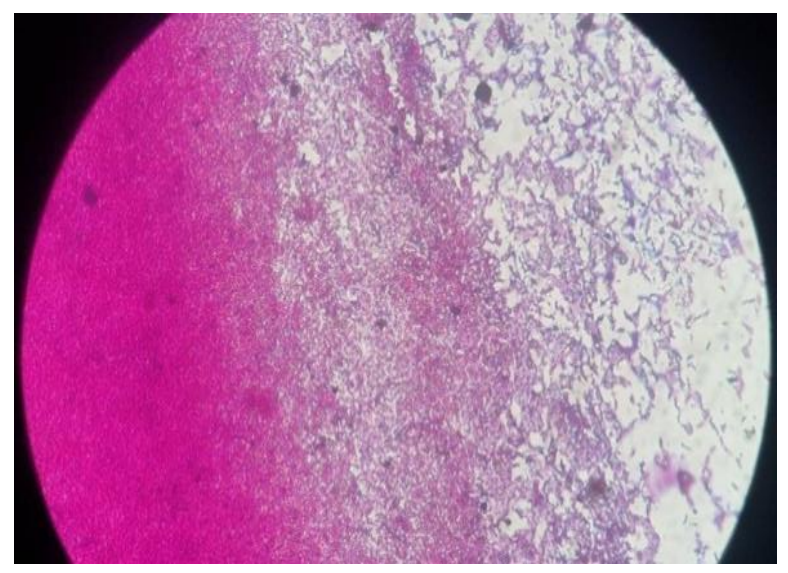

Gambar 3. Hasil Pewarnaan Gram 
Berdasarkan gambar 3. diperoleh hasil bakteri pencemar susu penyebab foodborne disease pada susu kemasan telah diidentifikasi menggunakan pengecatan gram, didapatkan bakteri gram (-). Bakteri didapat dari pewarnaan gram menghasilkan bakteri gram negatif memiliki dinding sel dengan lapisan peptidoglikan yang tipis, yang berwarna merah.

Penelitian dilakukan di Laboratorium Infeksi Rumah Sakit Umum Kabupaten Tangerang pada bulan Februari 2020. Pada penelitian ini menggunakan ekstrak kunyit kuning dan kunyit putih yang dibuat dengan cara diparut dan diperas dengan menggunakan kain saring untuk mendapatkan ekstrak kunyit guna mengetahui sensitivitas ekstrak kunyit kuning dan kunyit putih dengan mengukur zona hambat terhadap bakteri pencemar susu penyebab foodborne disease.

Sebelum dilakukan uji sensitivitas kunyit kuning dan kunyit putih, dilakukan terlebih dahulu uji koliform pada susu kemasan UHT yang sudah kedaluwarsa menggunakan media Lactosa Broth (LB). Tujuan dilakukannya uji koliform yaitu untuk mengidentifikasi bakteri koliform pada susu kemasan UHT yang sudah kedaluwarsa. Tabung yang mengandung bakteri koliform akan terdapat endapan, berubah warna menjadi coklat muda dan terdapat gas pada tabung durham. Hal ini menandakan terdapat bakteri koliform yang memfermentasikan laktosa. ${ }^{17}$

Pada hasil penelitian uji koliform 3 seri tabung $10^{-1}$ mengalami perubahan warna (merah menjadi kuning) seluruhnya, hal ini disebabkan karena pada 3 seri tabung $10^{-1}$ pengenceran susu lebih rendah dibandingkan dengan 3 seri tabung $10^{-2}$ dan $10^{-3}$ yang lainnya. Perubahan warna ini menandakan adanya aktivitas bakteri koliform.

Dari hasil yang didapat uji sensitivitas kunyit kuning dan kunyit putih yang di uji dengan metode Kirby Bauer menggunakan teknik difusi disk menunjukkan bahwa kunyit kuning pada konsentrasi $12,5 \%$ tidak membentuk zona hambat, konsentrasi $25 \%$ dapat membentuk zona hambat rata - rata sebesar $11,3 \mathrm{~mm}$, pada konsentrasi $50 \%$ dapat membentuk zona hambat rata - rata sebesar $15,3 \mathrm{~mm}$ dan pada konsentrasi $100 \%$ dapat membentuk zona hambat rata - rata sebesar 17 mm. Dari hasil uji sensitivitas kunyit kuning menyatakan bahwa konsentrasi suatu ekstrak sebanding dengan besarnya zona hambat. Terjadinya zona hambat tersebut dikarenakan adanya kandungan zat aktif pada kunyit kuning pada masing - masing konsentrasi dikarenakan kandungan senyawa kimia utama yang terkandung di dalam rimpang kunyit adalah minyak atsiri dan kurkuminoid. Didapatkan zona hambat yang berbeda pada masing - masing perlakuan, semakin besar konsentrasi yang diberikan maka semakin besar zona hambat yang terbentuk. ${ }^{19}$

Sedangkan kunyit putih tidak membentuk zona hambat terhadap bakteri pencemar susu penyebab foodborne disease. Kandungan utama kunyit putih adalah minyak atsiri, diperkirakan minyak atsiri sebagai komponen paling aktif berkhasiat diantara komponen - komponen lainnya. Namun kandungan ini dipengaruhi oleh habitat atau daerah tempat tumbuhnya. Rimpang kunyit putih tumbuh subur di daerah yang gembur daripada di daerah yang tandus, sehingga pembentukan minyak atsirinya menjadi lebih banyak. ${ }^{20}$

Kandungan bahan aktif pada kunyit juga dipengaruhi oleh umur panen, jika mencari kandungan terbaik disarankan menggunakan kunyit dengan umur 9 bulan. Hal ini dikarenakan pada umur 9 bulan, kandungan kunyit sudah terbentuk optimal. Tahap vegetatif kunyit telah berakhir yang ditandai dengan terjadinya kelayuan dan gugurnya daun, sehingga pada umur panen 10 bulan dan 11 bulan sudah tidak terjadi peningkatan produksi senyawa kurkumin. ${ }^{21}$

Tetrasiklin digunakan sebagai kontrol positif, tujuannya untuk membandingkan sampel dengan antibiotik yang sudah berpotensi sebagai zat antibakteri. Tetrasiklin merupakan antibiotik bakteriostatik berspektrum luas yang menghambat sintesis protein. Tetrasiklin bekerja aktif terhadap banyaknya bakteri gram positif dan gram negatif, 
termasuk bakteri anaerob, riketsia, klamidia, mikroplasma, dan terdapat beberapa protozoa, misalnya amoeba. ${ }^{22}$

Berdasarkan hasil pewarnaan gram yang telah dilakukan, bakteri pencemar susu penyebab foodborne disease pada susu kemasan yang telah diidentifikasi menggunakan pengecatan gram, didapatkan hasil bakteri gram (-) bewarna merah. Hasil yang didapat dari identifikasi bakteri yaitu bakteri berbentuk basil, sesuai dengan studi sebelumnya yang menyatakan bahwa bakteri patogen yang sering mencemari susu salah satunya Escherichia coli yang dapat menyebabkan diare pada manusia. Terdapat juga bakteri Salmonella sp. merupakan bakteri berbahaya yang dapat mencemari susu. Bakteri tersebut dikeluarkan dari saluran pencernaan hewan atau manusia bersama dengan feses. Oleh karena itu, produk yang berasal dari peternakan rentan terkontaminasi. Untuk susu yang telah memenuhi standar SNI, proses penyimpanan dan pendistribusian sampai ke tangan konsumen perlu diperhatikan. Meskipun telah melalui proses pasteurisasi, susu masih mengandung bakteri pembusuk, salah satu bakteri pembusuk pada susu yaitu Bacillus sp., bakteri pembusuk akan berkembang pada suhu ruangan. ${ }^{23}$

\section{SIMPULAN DAN SARAN}

Berdasarkan hasil penelitian ini, maka dapat disimpulkan bahwa terdapat sensitivitas kunyit kuning terhadap bakteri pencemar susu penyebab foodborne disease menggunakan metode Kirby Bauer dengan teknik difusi disk, dan tidak terdapat sensitivitas kunyit putih terhadap bakteri pencemar susu penyebab foodborne disease menggunakan metode Kirby Bauer dengan teknik difusi disk.

Hasil penelitian ini dapat digunakan sebagai penelitian lanjutan dengan menggunakan susu kemasan UHT yang tidak kedaluwarsa karena kasus keracunan setelah minum susu dapat terjadi karena kontaminasi selama penyimpanan maupun proses produksi, hasil penelitian ini juga dapat digunakan sebagai referensi bagi peneliti selanjutnya dan dapat dijadikan sebagai pengobatan alami dari tumbuhan yang dapat diperoleh dan diolah dengan mudah.

\section{TERIMAKASIH}

Terimakasih kepada kedua orang tua saya dan Laboratorium Infeksi Rumah Sakit Umum Kabupaten Tangerang.

\section{REFERENSI}

1. Haskito Ae, Sari C, Dameanti Fn. Gambaran Pengetahuan Siswa Sman 8 Malang Tentang Foodborne Disease. Arshi Veterinary Letters. 2019 Feb 28;3(1):15-6.

2. Yunus Sp. Hubungan Personal Higiene Dan Fasilitas Sanitasi Dengan Kontaminasi Escherichia Coli Pada Makanan Di Rumah Makan Padang Kota Manado Dan Kota Bitung.Jikmu. 2015;5(3).

3. Trimadya Nm, Hardjomidjojo H, Anggraeni E. Sistem Manajemen Risiko Kontaminasi Pada Rantai Pasok Pangan (Studi Kasus: Susu Pasteurisasi). Journal Of Agroindustrial Technology. 2018 Dec 20;28(2).

4. Prasetyo B, Kusumaningrum En. Deteksi Gen Tst Isolat Staphylococcus Aureus Melalui Amplifikasi 23s Rrna Asal Susu Kambing Dan Sapi Perah. Jurnal Kedokteran Hewan-Indonesian Journal Of Veterinary Sciences. 2014 Mar 1;8(1).

5. Utami Er. Antibiotika, Resistensi, Dan Rasionalitas Terapi. Sainstis.2012 Apr 23.

6. Adila R, Agustien A. Uji Antimikroba Curcuma Spp. Terhadap Pertumbuhan Candida Albicans, Staphylococcus Aureus Dan Escherichia Coli. Jurnal Biologi Unand. 2013;2(1).

7. Ibrahim Ta, Oyinloye Bo. 1. Antibacterial Activity Of Herbal Extracts Against Multi Drug Resistant Strains Of Bacteria From Clinical Origin By 1 Ta Ibrahim, 2 Bo Opawale And 3 Jma Oyinloye. Life Sciences Leaflets. 2011 May 1;15:490-To.

8. Pribadi Er. Pasokan Dan Permintaan Tanaman Obat Indonesia Serta Arah Penelitian Dan Pengembangannya.Perspektif. $2015 \quad$ Nov 19;8(1):52-64.

9. Meliki Rl, Lovadi I. Etnobotani Tumbuhan Obat Oleh Suku Dayak Iban Desa Tanjung Sari Kecamatan Ketungau Tengah Kabupaten Sintang. Protobiont. 2013;2(3). 
10. Auliani A, Fitmawati F, Sofiyanti N. Studi Etnobotani Famili Zingiberaceae Dalam Kehidupan Masyarakat Lokal Di Kecamatan Siak Hulu Kabupaten Kampar (Doctoral Dissertation, Riau University). 2014

11. Kusbiantoro D. Pemanfaatan Kandungan Metabolit Sekunder Pada Tanaman Kunyit Dalam Mendukung Peningkatan Pendapatan Masyarakat. Kultivasi. 2018 Mar 20;17(1).

12. Rahmawati N, Sudjarwo E, Widodo E. Uji Aktivitas Antibakteri Ekstrak Herbal Terhadap Bakteri Escherichia Coli. Jurnal Ilmu-Ilmu Peternakan. 2014;24(3):24-31.

13. Wientarsih I, Widhyari Sd, Aryanti T. Kombinasi Imbuhan Herbal Kunyit Dan Zink Dalam Pakan Sebagai Alternatif Pengobatan Kolibasilosis Pada Ayam Pedaging (The Combination Of Curcumin With Zinc In Feed As Alternatif Therapy Collibaciilosis In Broiler). Jurnal Veteriner. 2013;14(3):327-34.

14. Ekawati Er. Uji Efektifitas Perasan Kunyit Putih (Curcuma Spp.) Terhadap Pertumbuhan Escherechia Coli. Stigma: Jurnal Matematika Dan Ilmu Pengetahuan Alam Unipa. 2016 Nov 9;9(01).

15. Wijayanto W. Uji Aktivitas Antibakteri Ekstrak Etanol Rimpang Kunyit Putih (Curcuma Mangga Val.) Terhadap Staphylococcus Aureus Atcc 6538 Dan Escherichia Coli Atcc 11229 Secara In Vitro (Doctoral Dissertation, Universitas Muhammadiyah Surakarta). 2014

16. Harianto Ik. Uji Daya Hambat Perasan Rimpang Kunyit (Curcuma Longa L.) Terhadap Pertumbuhan Candida Albican.Pharmacon. 2017 May 2;6(2).

17. Patandung G, Ibrahim R. Uji Cemaran Bakteri Escherichia Coli Pada Jajanan Susu Kedelai Di Jalan Perintis Kemerdekaan Kota Makassar. Jurnal Farmasi Sandi Karsa. 2018;4(6):44-7.

18. Shinta DY, Hartono A. Uji Aktivitas Antimikroba Ekstrak Kulit Buah Naga (Hylocareus costarisensis) Terhadap E. coli, Staphylococcus aureus, dan Candida albicans. Sainstek: Jurnal Sains dan Teknologi. 2018 Jun 7;9(1):26-39.

19. Puspita A. Pengaruh Konsentrasi Ekstrak Kayu Manis (Cinnamomumburmanni) dalam Menurunkan Pertumbuhan Streptococcus Mutans Secara In Vitro (Doctoral dissertation, Universitas Muhammadiyah Surakarta). 2014

20. Astuti H. Komposisi Minyak Atsiri Rimpang Kunyit Putih (Curcuma Mangga Val.) Dari
Beberapa Daerah Di Diy Dengan Gcms. Majalah Farmaseutik. 2013;9(1):243-7.

21. Dewi Pj, Hartiati A, Mulyani S. Pengaruh Umur Panen Dan Tingkat Maserasi Terhadap Kandungan Kurkumin Dan Aktivitas Antioksidan Ekstrak Kunyit (Curcuma Domestica Val.). Jurnal Rekayasa Dan Manajemen Agroindustri. 2016;4(3):105-15.

22. Putri MA, Herawati D, Kurniaty N. Pengembangan Metode Analisis Antibiotik Tetrasiklin dalam Hati Ayam Menggunakan Kromatografi Cair Kinerja Tinggi (Kckt). 2015

23. Suwito W. Bakteri yang sering mencemari susu: deteksi, patogenesis, epidemiologi, dan cara pengendaliannya. Jurnal Penelitian dan Pengembangan Pertanian. 2016 Dec 5;29(3):96-100 